\title{
Effect of Problem Based Learning Learning Model to Improve Student Learning Outcomes
}

Siti Nurul Qomariyah ${ }^{1}$

\section{ARTICLE INFO}

Article History:

Received 19.10.2018

Received in revised form

17.01.2019

Accepted

Available online 01.04.2019

\begin{abstract}
This study was conducted to determine the effect of Problem Based Learning (PBL) learning models in improving learning outcomes of IPS 1 XI grade students at Pati 1 Pati. This study used quasiexperiment using the pretest-posttestcontrol class group. The population of this study was students of class XIIPS. The sample in this study was 80 students from 2 classes. 40 students of Class XI IPS 5 as an experimental class and 40 students in Class XI IPS 3 as a control class. Students in the experimental group were given a treatment with PBL learning models while students in the control class were given treatment of conventional learning models. The first phase sample selection technique was carried out using purposive sampling and the second stage using random sampling. Based on the findings, it can be concluded that there is an impact on the use of PBL and conventional models of economic learning outcomes. The PBL model has a signific ant influence on the economic learning outcomes of MAN 1 Pati.
\end{abstract}

(c) IJERE. All rights reserved

Keywords:

Problem Based Learning, conventional model, learning outcomes

\section{INTRODUCTION}

Education is a conscious effort and aims to develop quality (Djamarah, 2005). The understanding of education according to the National Education System Law No.20 of 2003 in (Munib , 2003) is a conscious and planned effort to create a learning atmosphere and learning process so that students actively develop their potential to have religious spiritual power, self-control, personality, intelligence, noble character, and skills needed by him, society, nation and state. Slameto (2010:2) learning is a learning process that is carried out by a person to obtain new behavioural changes as a whole, as his own experience in interaction with his environment.

According to Trianto (2010: 17) learning is an aspect of complex human activities, which cannot be fully explained. Learning is a system that aims to assist student learning, which contains a series of events that are designed, arranged in such a way as to influence and support the occur rence of student learning processes that are internal in nature.

Economic Learning is a subject that studies human behavior and actions to meet various and unlimited life needs and develops with limited resources through choices of production, consumption and distribution activities. Economic learning is expected to be able to take students to achieve maximum learning outcomes or achieve Minimum Completion Criteria (KKM). The hope that students are able to achieve the learning outcomes set by the government is 75 for KTSP and 2.66 for Curriculum 2013, not an easy job. The reality that occurs in economic learning is still problematic, namely "all class XI in MAN 1 Pati, after being given the first daily test it turns out that there is no one class that has achieved $100 \%$ completeness." (Economic Teacher Documents that carry out learning in class XI MAN Pati). The low student learning outcomes on economic subjects are one of the problems that teachers want to improve, for that we need a learning model for economic lessons to improve student learning outcomes. According to Djemari Mardapi (2008: 102), learning outcomes are determined by the quality of the learning process because learning outcomes are an ability or skill possessed by these students experiencing learning activities.

The success of the teaching and learning process is determined by the teaching model, namely how the teacher delivers the material to be taught. Hamruni (2012) suggests that teaching models are ways of presenting learning material to students to achieve the stated goals. Suprijono (2009) learning model is the basis of learning practices as a result of the decline in educational psychological theory and learning theory designed based on an analysis of curriculum implementation and its implications at the operational level in the classroom. Whereas Aunurrahman (2009) states the learning model can be interpreted as a conceptual framework that describes systematic procedures in organizing learning experiences to achieve certain

${ }^{1}$ Corresponding e-mail: sitinurulqomariyah22@gmail.com, orcid.org/0000-0001-6592-1968

University of Negeri Surabaya 
learning goals and serves as a guide for learning designers and teachers to plan and implement learning activities.

Fachrurazi (2011: 78) states that one of the learning models that can be used to improve the quality of processes and learning outcomes is the Problem Based Learning model. Problem-based learning has characteristics such as learning begins with giving problems, problems having context with the real world, students in groups actively formulating problems and identifying gaps in their knowledge in learning and searching for the material related to the problem and reporting solutions to problems. While educators facilitate more. The Problem Solving method (problem-solving method) is not just a teaching method but also a method of thinking, because in the Problem Solving method it can use other methods starting with finding data to draw conclusions (Djamarah \& Zain, 2010: 91).

Problem-based learning is focused on problems where students can build their own knowledge, develop inquiry and thinking skills to a higher level. Students must be able to formulate temporary answers to problems that require logical intelligence, courage and active solutions in real situations. Students also need to increase their independence, confidence and endurance to solve problems (Talib and Kailani, 2014). According to Sanjaya (2007) Problem Based Learning (PBL) is a series of learning activities that emphasize the process of solving problems faced scientifically. According to Glatthorn and Craft-Tripp (in Pecore, 2012) Problem Based Learning is a learning model based on constructivism theory that will make students' interest in learning and participating actively in the learning process. According to Muraray-Harvey, Pourshafie, and Reyes (2013) one way to make active learning is to apply a problem-based learning model. Sudjana (2011) states that learning outcomes are abilities possessed by students after receiving their learning experience.

\section{METHOD}

The type of research conducted is quantitative research. This study uses quasi-experimental methods (quasi-experiment), which is a study that is used to find the effect of certain treatments on others in controlled conditions, other variables that can affect the experimental process can be tightly controlled (Sugiyono, 2008: 107). The study was conducted in XI IPS MAN 1 Pati class 2018/2019 academic year in August 2018 until October 2018. The population in this study were students of class XI IPS MAN 1 Pati, amounting to 240 people consisting of 150 female students and 90 male students and spread across 6 (six) classes.

The samples were students of class XI IPS 3 and XI IPS 5. Data collection in this study used tests (pretest and post test in the experimental class and the control class). The test instrument used in this study has a very high-reliability value of 1.00 . Requirement test uses version 21 statistical product and service solution (SPSS). The requirement test used is normality using Kolmogorov-Smirnov and variance homogeneity test using the Lavena test. Hypothesis testing uses t-test with the help of SPSS version 19. The dependent variable in this study is the result of economic learning. the dependent variable in this study is the PBL learning model.

This quasi-experimental study was conducted with the control group design - posttest pretest. At first, both the experimental and control classes will be given a pretest before using the learning model. Posttest is given at the end of the learning process to determine the extent to which effective learning models to improve student learning outcomes

\section{RESULTS AND DISCUSSION}

The research data is described by displaying the results of the pre-test and post-test both experimental and control classes. 
Table 1. The results of the pre-test experimental class and the control class

\section{Results of the pre-test}

\begin{tabular}{|c|c|c|c|c|c|c|}
\hline $\begin{array}{ll}\text { Learning } & \text { Class } \\
\text { Approach } & \end{array}$ & I & $\mathrm{N}$ & Mean & $\mathrm{Sd}$ & $\begin{array}{l}\text { The highest } \\
\text { score }\end{array}$ & Lowest value \\
\hline $\begin{array}{l}\text { Experimental } \\
\text { (PBL model) }\end{array}$ & Class & 30 & 52,00 & 10.298 & 73 & 31 \\
\hline $\begin{array}{l}\text { Control } \\
\text { (Conventional Mode }\end{array}$ & $\begin{array}{l}\text { Class } \\
\text { el) }\end{array}$ & 30 & 48.55 & 7.548 & 60 & 31 \\
\hline
\end{tabular}

Table 1 shows that the results of the experimental class pre-test using the PBL model and the control class using the conventional model did not differ significantly because the mean of the experimental class 52.00 was only a difference of 3.45 with the mean of the control class reaching 48.55. After two research classes were taught with two different learning models, each of these data was tested for normality and homogeneity, both after the pretest and posttest.

Table 2. The results of the pre-test data normality test.

Learning model Kolmogorov-Smirnov

Conclusion

o

\begin{tabular}{llll}
\hline Df & Statistic & Sig & \\
40 & 0.112 & 0.20 & Normal \\
40 & 0.135 & 0.060 & Normal
\end{tabular}

Based on the table above shows that the pre-test score data for the PBL model in the experimental class obtained sig 0.060 , because the sig value is greater than 0.05 , it can be explained that there is no significant difference between the data tested with standard normal data so that the data tested are norm al.

Table 3. The results of the post-test data normality test

Learning model

o

Conventional Model

PBL model
Kolmogorov- Smirnov

Df $\quad$ Statistic $\quad$ Sig

0.126

0.110

40

0.117

0.175

Normal

Conclusion

Normal

Based on the table above shows that the post-test score data for the PBL model in the experimental class obtained sig 0.175 , because the sig value is greater than 0.05 so it can be explained that there is no significant difference between the data to be tested with standard normal data so that the data tested are normal. The post-test results for the control class or those using the conventional model obtained a sig value of 0.110 which was above sig. 0.05, it can be concluded that there was no difference between the data to be tested with standard normal data or concluded that the data were normally distributed.

2.HomogeneityTest

Table 4. The homogeneity of the experimental class and the control class

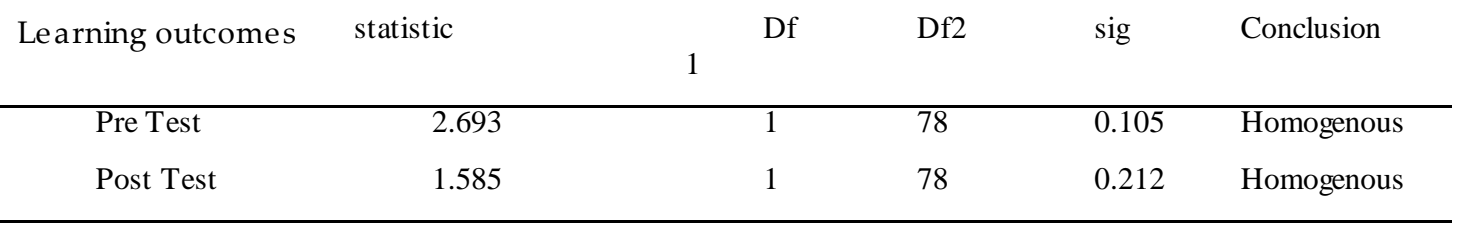


The results of homogeneity tests show that economic learning outcomes data seen from the PBL model originating from the population come from the same sample so that the results are homogeneous, this is indicated by Sig. $>0.05$.

\section{Test the Hypothesis}

In testing the hypothesis, the t-test analysis is used. The $t$-test analysis was directed at the pre-test and post-test learning outcomes.

Table 5. learning outcomes pre-test economic subjects with t-test

Independent samples test

\begin{tabular}{|c|c|c|c|c|c|c|c|c|c|c|}
\hline & \multirow{2}{*}{\multicolumn{2}{|c|}{\begin{tabular}{lr}
\multicolumn{2}{r}{ Levene's } \\
Test $\quad$ for \\
Equality of \\
Variances
\end{tabular}}} & \multirow{2}{*}{\multicolumn{7}{|c|}{ t-test for Equality of Means }} \\
\hline & & & & & & & & & & \\
\hline & & $\bar{F}$ & Sig. & \multirow[t]{2}{*}{$\mathrm{t}$} & \multirow[t]{2}{*}{$\mathrm{df}$} & \multirow[t]{2}{*}{$\begin{array}{l}\text { S } \\
\text { ig. } \quad(2- \\
\text { tailed) }\end{array}$} & \multirow[t]{2}{*}{$\begin{array}{l}\text { Mean } \\
\text { difference }\end{array}$} & \multirow[t]{2}{*}{$\begin{array}{l}\text { Std. error } \\
\text { difference }\end{array}$} & \multicolumn{2}{|c|}{$\begin{array}{l}\text { 95\% } \\
\text { Confidence Interval } \\
\text { of the Difference }\end{array}$} \\
\hline & & & & & & & & & Lower & Upper \\
\hline \multirow[t]{2}{*}{$\begin{array}{l}\text { Learni } \\
\text { ng outcomes } \\
\text { pre-test }\end{array}$} & $\begin{array}{l}\text { Equal } \\
\text { Variances } \\
\text { assumed }\end{array}$ & 2.693 & .105 & 1.709 & 78 & .091 & 3.450 & 2.019 & -.569 & 7.469 \\
\hline & \begin{tabular}{l}
\multicolumn{1}{c}{ Equal } \\
V ariances not \\
assumed
\end{tabular} & & & & 71.518 & .092 & 3.450 & 2.019 & -.575 & 7.475 \\
\hline
\end{tabular}

Based on the table above shows that based on sig (2-tailed) $=0.025$, it can be said that $\mathrm{H} 0$ is rejected, meaning that both groups have the same pre-test learning outcomes. So, judging from the results of the pretest of economic subjects between the experimental classes, the PBL model and the control class given the
conventional
model
had
no
difference.

Table 6. post-test results of economic subjects with t-test

Independent samples test

\begin{tabular}{|c|c|c|c|c|c|c|c|c|c|c|}
\hline & \multicolumn{2}{|c|}{$\begin{array}{l}\text { Levene's Test for } \\
\text { Equality of } \\
\text { Variances }\end{array}$} & \multicolumn{7}{|c|}{ t-test for Equality of Means } \\
\hline & & \multirow[t]{2}{*}{$\mathrm{F}$} & \multirow[t]{2}{*}{ Sig. } & \multirow[t]{2}{*}{$\mathrm{t}$} & \multirow[t]{2}{*}{$\mathrm{df}$} & \multirow[t]{2}{*}{$\begin{array}{l}\text { Sig. (2- } \\
\text { tailed) }\end{array}$} & \multirow[t]{2}{*}{$\begin{array}{l}\text { Mean } \\
\text { difference }\end{array}$} & \multirow[t]{2}{*}{$\begin{array}{l}\text { Std. error } \\
\text { difference }\end{array}$} & $\begin{array}{l}95 \% \\
\text { Interval } \\
\text { Difference }\end{array}$ & $\begin{array}{c}\text { Confidence } \\
\text { of the }\end{array}$ \\
\hline & & & & & & & & & Lower & Upper \\
\hline \multirow[t]{2}{*}{$\begin{array}{l}\text { Learning } \\
\text { outcomes } \\
\text { post-test }\end{array}$} & $\begin{array}{l}\text { Equal } \\
\text { Variances } \\
\text { assumed }\end{array}$ & 1.585 & .212 & 11.300 & 78 & .000 & 20.175 & 1.785 & 16.621 & 23.729 \\
\hline & $\begin{array}{l}\text { Equal } \\
\text { Variances not } \\
\text { assumed }\end{array}$ & & & 11.300 & 76.971 & .000 & 20.175 & 1.785 & 16.620 & 23.729 \\
\hline
\end{tabular}

Based on the table above, the two groups have the same variance because the value of sig is $0.212>$ 0.05. then based on t-test, the value of sig 0,000 is obtained so that $\mathrm{H} 0$ is accepted. This means that the two groups, namely the experimental class given the PBL learning model and the control class with conventional learning models do not have the same post-test results of the same economic subjects or post-test learning outcomes for the economic subjects of the two classes are different. 


\section{DISCUSSION}

Based on the results of testing the $t$-test statistics, the calculated $F$ value is 1.585 with a sig value of 0,000 smaller than the alpha value of 0.05 which means the null hypothesis is rejected and the alternative hypothesis is accepted which states there are differences in learning outcomes between groups of students who are taught using PBL models compared to groups students who are taught conventional models. This difference is reinforced by data on the mean acquisition of each group. Learning in the experimental class using the PBL model obtained a mean of 79.10 while the mean obtained in the conventional learning model in the control class was 58.93. From this analysis, the average learning outcomes of PBL models are higher than learning outcomes in groups of students who use conventional models with a very significant difference of 20.17 .

Based on the research of Kusumatuty et al (2018) show s that the application of e-book learning based on problem-based learning is effective to improve student learning outcomes. there are relevant differences between the value of the experimental class and the control class so that student learning outcomes in the experimental class are better than the implementation of problem-based learning (PBL) in the control class

Significant differences between groups of students who studied with the PBL model and groups of students who studied with conventional models showed learning outcomes influenced by learning models. This finding proves the truth of previous theoretical studies that the learning model influences learning outcomes. Specifically Anna Sylvia et al (2017) explained that the use of PBL learning models can make it easy for students to understand the lessons so that students can achieve better learning outcomes. (Heri Mulyanto 2018) said that there were significant differences in mathematics learning outcomes between students who learned to follow the Problem Based Learning learning model with conventional models. The findings of this study are also in line with Sanjaya (2008:220), which among others states that problem -based learning is a good technique for better understanding the content of the lesson, giving satisfaction to finding new knowledge for students, and increasing student learning activities.

Warsono and Hariyanto (2013: 149) state that "problem-based learning (often called PBI (problembased instruction) is a type of classroom management needed to support the constructivism approach in teaching and learning." This is of course different from conventional learning approach. The conventional model is only able to empower students with auditory potential. Djamarah (2008: 56) states that conventional learning methods have always been used as a means of oral communication between teachers and students in the process of learning and learning. From this theoretical perspectiveit can be understood if later the findings of this study prove the existence of differences in economic learning outcomes that use PBL models with conventional models because practically, conventional models rely solely on one learning potential that is auditory.

The entire discussion that has been put forward provides empirical beliefs that strengthen the theoretical belief that the PBL model applied to the experimental class can improve student learning outcomes on economic subjects in MAN 1 Pati higher than the conventional model applied to the control class.

\section{CONCLUSION}

Based on the conclusions of this study, teachers are advised to increase routine meetings in the Teacher Working Group to discuss the use of PBL learning models. Principals are advised to support teachers in implementing learning innovations through w orkshops or home training. Further research is recommended to expand the study sample in public and private elementary schools in the Central Java region, so that the results of the study can be more generalized. In addition, there is still a need for research to analyze the differences in mathematics learning outcomes by comparing problem-based learning with other models, so that the results will be more developed.

\section{REFERENCES}

Aunurrahman (2009). Belajar dan Pembelajaran. Bandung: Alfabeta

Djamarah, S. B. (2005). Guru dan Anak Didik Dalam Interaksi Edukatif. Jakarta : Rineka Cipta. 
Qomariyah,S.N.(2019).Effect of problem based learning learning model to improve student learning outcomes. International Journal of Educational Research Review,4(2),217-222.

Hamalik, O. (2011). Proses belajar mengajar. Jakarta: Bumi Aksara

Hamruni (2012). Strategi pembelajaran.Yogyakarta : Insan Madani

Kusumatuty, A. J, Baedhowi \& Murwaningsih, T. (2018). The implementation of problem based learning (Pbl) based ebook to improve the learning outcome of vocational high school (Vhs) students.International Journal of Educational Research Review, 3 (4),103-110

Mardapi, D. 2008. Tehnik penyusunan instrumen Tes dan Non Tes. Jogjakarta : Mitra Cendika

Mulyanto, H., Gunarhadi \& Indriayu, M. (2018). The effect of problem based learning model on student mathematics. Learning outcomes viewed from critical thinking skills .International Journal of Educational Research Review,3(2),37-45.

Murray-Harvey, R., Pourshafie. T., \& Rayes, S. W. (2013). What teacher education students learn about collaboration from problem-based learning. Journal of Problem Based Learning in Higher Education,1(1), 114-134.

Munib, A. (2006). Pengantar Ilmu Pendidikan. Semarang : Unnes Press

Rosnawati, H. (2008). Penggunaan Teknik Probing Untuk Meningkatkan Pemahaman Konsep Matematika Siswa SMP. Skripsi pada Jurusan Pendidikan Matematika UPI Bandung: tidak diterbitkan.

Suherman, dkk. (2001).Strategi Pembelajaran Matematika Kontemporer.Bandung:JICA UPI.

Sudarti, T. (2008).Perbandingan Kemampuan Penalaran Adatif Siswa SMP Antara yang Memperoleh Pembelajaran Matematika Melalui Teknik Probing dengan Metode Ekspositori.Skripsi pada Jurusan Pendidikan Matematika UPI Bandung: tidak diterbitkan

Suherman, E. dan Sukjaya, Y. (1990). Petunjuk Praktis untuk Melaksanakan Evaluasi Pendidikan Matematika. Bandung:Wijaya kusuma h 157.

Sudjana, N. (2011). Penilaian Hasil Proses Belajar Mengajar. Bandung: PT Remaja Rosdakarya.

Suprijono,A.(2009). Cooperative Learning: Teori dan Aplikasi Paikem. Yogyakarta: Pustaka Pelajar.

Slameto (2010). Belajar dan faktor-faktor yang mempengaruhinya.Jakarta: Asdi Mahasatya.

Trianto (2009). Mendesign Model Pembelajaran Inovatif Progresif. Jakarta:Kencana 